\title{
To Call or Not to Call a Spade a Spade: The Dilemma of Treating 'Offensive' Terms in Duramazwi Guru reChiShona*
}

\author{
Emmanuel Chabata (emmanuelchabata@yahoo.com) and \\ Webster M. Mavhu (vhezh2000@yahoo.com), African Languages Research \\ Institute (ALRI), University of Zimbabwe, Harare, Zimbabwe
}

\begin{abstract}
As noted by Béjoint (2000: 6), the main objective in dictionary-making is to define words and terms. This is especially the case if the fact is accepted that dictionaries are mostly consulted for word meaning and that, in the consultation process, the user hopes to acquire and/or verify certain information. However, as again noted by Jackson (1988), Landau (1984), Svénsen (1993) and Zgusta (1971), among others, the description of word meaning is one of the greatest difficulties with which the lexicographer has to cope. This article discusses some of the challenges facing lexicographers when defining 'offensive' headwords in a monolingual dictionary. It is based on experiences of defining such headwords for the general-purpose, medium-sized, synchronic, monolingual Shona dictionary, Duramazwi Guru reChiShona (henceforth DGC) (Chimhundu et al. 2001). DGC was compiled and edited by a six-member team of mother-tongue speakers of Shona who are researchers at the African Languages Research Institute (ALRI). The article also discusses some of the strategies the team of editors adopted as ways of dealing with offensive words in DGC. One such strategy is the use of euphemism in defining.
\end{abstract}

Keywords: ALRI, CULTURE, DEFINITION, THEORETICAL DEFINITION, PRACTICAL DEFINITION, DICTIONARY, EUPHEMISM, LEXICOGRAPHY, MONOLINGUAL DICTIONARY, OFFENSIVE HEADWORD, SHONA

Opsomming: Om die kind by sy naam te noem of nie te noem nie: Die dilemma van die behandeling van "aanstootlike" terme in Duramazwi Guru reChiShona. Soos deur Béjoint (2000: 6) opgemerk, is die hoofdoel van woordeboekmaak om woorde en terme te definieer. Dit is veral die geval as die feit aanvaar word dat woordeboeke meestal geraadpleeg word vir woordbetekenis en dat, by die raadplegingsproses, die gebruiker hoop om sekere inligting te bekom en/of te kontroleer. Soos weer eens opgemerk deur onder andere Jackson (1988), Landau (1984), Svénsen (1993) en Zgusta (1971), is die omskrywing van woordbetekenis egter een van die grootste moeilikhede wat die leksikograaf moet hanteer. Hierdie artikel bespreek sommige van die uitdagings waarvoor leksikograwe te staan kom wanneer "aan-

* This article was presented as a paper at the Seventh International Conference of the African Association for Lexicography, organised by the Dictionary Unit for South African English, Rhodes University, Grahamstown, Republic of South Africa, 8-10 July 2002. 
stootlike" trefwoorde in eentalige woordeboeke gedefinieer word. Dit is gebaseer op die ervarings by die definiëring van sulke trefwoorde vir die meerdoelige, mediumgroot, sinchroniese, eentalige Sjonawoordeboek, Duramazwi Guru reChiShona (voortaan DGC) (Chimhundu et al. 2001). DGC is saamgestel en geredigeer deur 'n span van ses moedertaalsprekers van Sjona wat navorsers by die African Languages Research Institute (ALRI) is. Die artikel bespreek ook sommige van die strategieë wat die redakteurspan gekies het as maniere om aanstootlike terme in DGC te behandel. Een so 'n strategie is die gebruik van eufemismes by definiëring.

Sleutelwoorde: ALRI, KULTUUR, DEFINISIE, TEORETIESE DEFINISIE, PRAKTIESE DEFINISIE, WOORDEBOEK, EUFEMISME, LEKSIKOGRAFIE, EENTALIGE WOORDEBOEK, AANSTOOTLIKE TREFWOORD, SJONA

\section{Introduction}

Defining is one of the most important stages in the compilation of a dictionary. Although it has become the norm in modern lexicography also to include information about the spelling, pronunciation, etymology, etc. of words, the most central information is about the description of their meaning. Meaning is even more central when it concerns monolingual dictionaries. In his description of monolingual dictionaries, Landau (1984: 8) says:

A monolingual dictionary provides many kinds of information about its entry words but most importantly gives definitions ... The chief purpose of a monolingual dictionary is to explain, in words likely to be understood by native speakers, what other words mean.

The importance attached to meaning in monolingual dictionaries means that defining should be taken seriously. But what should a lexicographic definition giving the word meaning do or be like? According to Landau (1984: 120), a definition should be equivalent to or should capture the essence of the thing defined. It should be as informative and as enlightening to the reader as possible. To do this, a dictionary definition should be based on truth, clarity, accuracy and preciseness. It should say what a word means, explicitly. In other words, the description should both be pointed and direct, which is one of the basic principles of defining. A dictionary definition should be a description of a thing that enables the reader to recognise the thing when he/she sees it or feel it when he/she gets in touch with it, either physically or mentally. This kind of definition does not have any biases and is not conditioned by such factors as cultural, social, geographical, racial or historical context. Such is the theoretical or ideal dictionary definition, where a spade is called by its name.

The theoretical definition described above is objective. Objectivity is an important principle to achieve, especially if the fact is recognised that a dictionary is a normative and didactic reference tool, that it is an instrument primarily consulted when searching for information about a word in particular, about language in general or about the world at large. As noted by Béjoint (2000: 18- 
19), dictionaries are instruments of self-teaching for, during the consultation process, their users learn or verify something that they did not know or that they had momentarily forgotten. It is because of this very important role that dictionaries have in society that the information they contain should be presented in an objective way.

However, dictionary-making is not entirely a theoretical enterprise; it is also a practical exercise. In addition to observing the principles guiding the compilation of dictionaries, lexicographers should also pay attention to the needs, expectations and cultural norms of their target users. Landau (1984: 121) notes:

Lexicography is a craft, a way of doing something useful. It is not a theoretical exercise to increase the sum of human knowledge but practical work to put together a book that people can understand ... Every lexicographer, like any good author, has his readers very much in mind.

The lexicographer's pen is sometimes not free to write its owner's views and convictions. The lexicographer is more often than not forced to write in a manner that does not invite controversies or disputes about his/her work or that does not disconcert a section of the society he/she intends to inform. In other words, he/she is forced to sacrifice some principles of his/her profession for the sake of pleasing the users for whom he/she is writing.

From this discussion, it can be noted that two aspects need to be balanced when defining, that is, the theoretical principles on which the lexicographer bases his/her definitions on the one hand and the cultural context in which the lexicographer is working on the other. A balance between these brings about good lexicographic practice. The process of trying to balance these two aspects makes defining a very complicated stage in dictionary-making. The reason for this is that the theory behind defining sometimes conflicts with the cultural norms as well as the expectations of the target users which the lexicographer should also observe.

In the consecutive sections of this article, the challenges the compilers of Duramazwi Guru reChiShona (henceforth DGC) faced in their treatment of offensive terms will be discussed. Their dilemma concerned their decision whether to be faithful to the theoretical aspect of defining (that is, being explicit and direct in their descriptions) or to follow the practical path (which implies being euphemistic). However, it may first be necessary to briefly look at the principles that guided the headword and sense selection processes of DGC.

\section{Headword and sense selection in DGC}

Headword and sense selection processes are of paramount importance in the compilation of any dictionary. These are the processes that determine the major contents of a particular reference work. As noted by Landau (1984: 185), the 
decision to include or exclude a particular category of words and/or senses relates directly to the purpose of the dictionary. He argues that if a dictionary is conceived of as purely descriptive, then every word documented as being in sufficiently wide use should be included, no matter how objectionable. In the same vein, Trench (1857) (quoted by Béjoint 2000: 119) argues that, being an inventory of the language, a general dictionary should be descriptive; hence, it should include all the words used by speakers of the language. Trench rejects the idea that the dictionary-maker should only select words considered to be "good" or "appropriate" in a dictionary, at the same time omitting those that are felt "bad" or "inappropriate". He further accentuates that the task of the lexicographer, who he describes as a historian and not a critic, is to collect and arrange all the words despite the fact that they may or may not sound good or appropriate. What Landau and Trench say about headwords to be included in a dictionary can also be said about the kinds of meanings the words should carry.

DGC was meant to be a comprehensive description of Shona. It was intended to be a general purpose dictionary describing all possible Shona words and their meanings and/or usages in the different Shona communities by speakers of all ages and in all possible contexts. As such, it was supposed to be as inclusive as possible of the whole vocabulary and complete usage of the language. No category of words or word meanings was regarded as unsuitable for inclusion in the dictionary. This was unlike the case with Duramazwi reChiShona (henceforth DRC) (1996), the forerunner of DGC, where some categories of words such as offensive and other terms were avoided for a number of reasons.

DRC was intended as a reference tool mainly for use by secondary school students, and the inclusion of offensive terms, for example, was believed to be "dangerous" to young users. In a few cases where such terms did find their way into the dictionary, the description of their meanings was left vague for fear of their sensitivity. However, as has already been noted, DGC was firstly intended to be a more comprehensive reference work also meant for adults who include Shona teachers and students studying at higher secondary and tertiary education levels. Secondly, the compilation of DGC was corpus-based, although, of course, it was not necessarily corpus-bound. The team of compilers of the dictionary decided to include all words and senses gleaned from the Shona linguistic corpus. The idea behind this decision was that the existence of the different words and word usages in the corpus was enough evidence that these words and senses were in use by Shona speakers. The implications of being corpus-based were that the majority of headwords, senses, citations and other relevant linguistic information required for the compilation of the dictionary would come from the Shona corpus. The corpus, which currently comprises approximately three million running words, was built from oral and written materials focusing on a wide range of aspects of Shona life. Among the words that feature in the corpus and that had to be selected as headwords for inclusion in DGC, were offensive words. 


\section{Offensive words in Shona}

To clearly understand the position of offensive terms in Shona the reality that every society has a culture shaping its people's worldview needs firstly to be accepted. Since they have a certain way of viewing the world, the people tend to have some biases towards ideas that prevail in their society, at the same time being critical of those ideas that go against the way they are looking at life. A people's worldview can be seen through the people's attitudes towards factors such as, among others, social behaviour, dressing, eating habits, and of course language use. When it comes to language, people in any culture tend to have their preferred styles of speaking as well as words and expressions they believe to contain their distilled knowledge about life, acquired through their experiences over generations. On the other hand, they also have words and expressions they think should not be used, those they even discourage their children from uttering. This latter category includes offensive and/or taboo words a person should strive to avoid in speech. For purposes of discussion in this article, offensive and/or taboo words will be taken to refer to a variety of words that may be considered vulgar, obscene, impolite, insulting and derogatory, those referring to the physically deformed or mentally impaired and all those usually being avoided or normally found unacceptable in the Shona cultural context. Words in this rough category are considered unsuitable for use by any "normal" person. Their use goes against the norms of good behaviour for they are either injuring the dignity or hurting the feelings of an individual or social group in whose presence they may be used or to whom they may refer.

A large body of offensive words in Shona consists of those that may be called obscene. Obscenity has been described by Landau (1984: 183) as "any reference to the bodily functions that gives to anyone a certain emotional reaction, that of 'fearful thrill' in seeing, doing or speaking the forbidden. Thus, it is the existence of the ban or taboo that creates the obscenity". As can be inferred from this quotation, obscene words are mostly those that refer to certain parts of the human anatomy as well as their functions. These are usually the private parts of the body that have to do with sex and excrement and whose exposure in public is seen as taboo. The following are a few illustrative examples of Shona words that may be regarded as obscene: mboro (penis), beche (vagina), chindori (clitoris) and jende (testicle). Obscene words also include those referring to the excretory organs and/or bodily processes. Examples of such terms in Shona are mukosho (anus), -mama (defecate), -tunda (urinate/ejaculate) and -sura (fart). Such words are socially so restricted that they may not be used in public without causing embarrassment either to the speaker or to the listener(s). However, it must be stressed that obscenity is circumstantial. Although these terms are discouraged or prohibited in speech they may be used freely in appropriate circumstances. For example, they are licensed for use when people are intimate or when maturing youths are taught about sex and sexuality. 
Offensive words also include those terms generally considered insulting. Some examples of insulting words in Shona are musatanyoko (referring to the genitals), nyamai and musvirinyoko (both referring to the referent's mother's vagina) and shiti (shit). To offensive terms further belong derogatory racial or ethnic words used to refer to individuals or groups whose heriditary appearance, geographical origin or social status are regarded as inferior. Among examples of derogatory terms in Shona are words such as murungudunhu/ murungudondo (albino), mukarushu (person of Mozambican origin), bwidi (person of Malawian origin) and dzviti (a Ndebele person).

In Shona culture, just as in most African cultures, the use of offensive words in ordinary speech is normally unacceptable. Although most speakers of Shona may be aware of the existence of these offensive words, they may not use them freely to refer to events, activities, objects or people. They are generally believed to be sensitive, thus they may not be used without offending those who care about cultural and social norms and good behaviour. In this case, therefore, sensitive words are not normally used for fear of offending other people. Instead, people would prefer the use of equivalent but indirect terms in place of such words, as this is usually believed to be culturally and socially polite, testifying to good manners. In the following section, the treatment of some of the examples of offensive terms in DGC is considered.

\section{Treatment of offensive words in DGC}

In the previous sections, it has been noted that the objective of compiling DGC was an attempt to produce a comprehensive description of the Shona language in its possible totality. Part of this objective entailed the insertion of all possible words in the dictionary, including offensive terms which can either be obscene or insulting. The principles guiding the creation of definitions for dictionary headwords had also been considered. Particulary because general-purpose dictionaries such as DGC serve as instruments for self-education and social integration (Béjoint 2000: 21), dictionary definitions should be as informative, enlightening and explicit as possible. A close analysis of these few points shows that, as far as Shona monolingual lexicography is concerned, there is a conflict between producing an effective self-educative tool and producing a socially compatible tool. Given all this, one is tempted to ask: What is the position of the Shona lexicographer in all this, and how can good lexicographic practice be achieved in this situation?

Dubois and Dubois (1971) (quoted in Béjoint 2000: 20) describe the role of the lexicographer as that of a "mediator" between society and its people, as a mouthpiece of his/her society. If this description of Dubois and Dubois is anything to go by, then lexicographers (and hence the dictionaries they produce) are not free from ideological biases characterising the society/-ies from which they come. In other words, the social ideology of the speakers of the language being described is the one determining the way words should be defined in 
dictionaries. This social ideology, for example, determines the extent to which the objectivity principle can be upheld in the compilation of a dictionary of any kind. The role of the lexicographer is to try to balance the dictates of his/her profession and the demands of the culture he/she is trying to portray and of the people he/she is writing for. In a bid to strike a balance between these two aspects, lexicographers face a number of challenges. The challenges the compilers of DGC faced with regard to the treatment of offensive words will be discussed in two stages, that is, (a) whether offensive words should be included in or excluded from the dictionary, and (b) if they are included as dictionary entries, how the meanings of these words should best be described.

Initially the editors had decided to entirely exclude offensive words from DGC. For a number of reasons, exclusion was to be the easiest option for the editors to handle them. As has already been stated, offensive words are not freely and openly used in Shona culture, whether in speech or in print. All the editors being mother-tongue speakers of Shona entails that their lives and backgrounds are deeply rooted in Shona culture. The cultural issue is one factor that made the editors of the dictionary experience some discomfort with the idea of including offensive words in the dictionary. This discomfort came from the realisation that, as lexicographers, they were expected to respect their society's cultural norms and morals with regard to the limits of what is communicable to the public. Another reason causing discomfort was the educational background of the editors who all had primary and secondary education at Christian mission schools where Christian morality was a priority. The emphasis on an adherence to the "good" and an avoidance of the "bad" indirectly affected the editors when it came to the selection of offensive terms as headwords in the dictionary. This was also compounded by the editors' consciousness of the fact that the dictionary would be used in Zimbabwe's educational system where there exists a policy discouraging writers and artists from explicitly using and describing offensive terminology in school books.

The editors were furthermore conscious of the criticism launched at DRC, DGC's forerunner, by some Shona conservatives. When DRC was published in 1996, one prominent scholar reviewed the dictionary. Although offensive headwords were entered with caution and were defined with discretion, keeping the target users in mind (Mberi et al. 1997: 24), the reviewer attacked the editors for entering and defining the terms in the dictionary. He commented, for example, that "the degree of specificity of most of the items goes beyond what the reader who is a native speaker wants to know" (Kahari 1996-97: 38). He further alleged that by containing offensive entries, the dictionary lacked "traditionally accepted taste and decorum". Thus, the editors of DGC had to be very careful when dealing with offensive words since some conservatives were likely going to focus on such words in their analysis of the dictionary.

However, the lexicographers had the principles of their trade to consider as well. Since the purpose of the dictionary was to give a description of Shona, the expectation was that all the words used in the language were to be fully 
documented in it. Excluding some words, and more so, categories of words, could lead to some form of deficiency of the work since it would leave out a portion of the language as it is used by its speakers. The result, therefore, would not be a truthful picture of the way the language is used. Excluding them would also be an act of ignoring the Shona corpus since most of these terms appear in it. The existence of these words in the Shona oral corpus is evidence enough that the terms are used in communication and therefore qualify them for inclusion in the dictionary. Some people would argue that including them in a dictionary is a way of licensing them for use, even by young children who are often cautioned to avoid them. The argumentation accompanying this view is that dictionaries are authoritative reference works and whatever is found in them is public knowledge that can be used or referred to at any time without restriction. However, real life experiences have shown that even when children are not taught or encouraged to use offensive words, somehow they end up using them, whether they appear in the dictionary or not. The fact that children use these words is also evidence that they are used in the society. Otherwise, how else could they have acquired this vocabulary? Eventually, the decision was that offensive terms should be included in the dictionary. However, the challenge then was how to describe the meanings of these words.

With regard to defining offensive headwords, a deliberate decision was made to avoid using explicit and direct terms in descriptions. Instead, the editors would use euphemism as much as possible, without, however, losing the actual essence of a word's meaning. As noted in Holder (1995), "euphemism means (the use of a) mild or vague or periphrastic expression as a substitute for blunt precision or disagreeable truth". Sinclair (1995) says that "if you describe language as euphemistic, you mean that it uses polite, pleasant, or neutral words and expressions to refer to things which people find unpleasant, upsetting or embarrassing". From this, it can be concluded that euphemism is a language of evasion and avoidance. It tends to evade and avoid the explicit and direct and advocates the implicit and indirect. However, its use was regarded as a way of being courteous to users and of showing respect for societal norms. This is because it comprises words and expressions specially created or crafted to substitute those explicit and direct terms that cannot be used in public.

It should now be considered how a few of the offensive words given as illustrative examples above were treated in DGC. As far as grammatical information is concerned, these offensive words were treated similarly to nonoffensive lemmas, giving tone (D, dzikisa, low tone, $\mathrm{K}$, kwidza, high tone, $\mathrm{D}-$, low tone throughout, K-, high tone throughout), part of speech ( $\mathrm{z}$, zita, noun) and noun class (indicated by numbers). However, the subsequent treatment was supposed to be as discreet as possible. The arrangement of the entries of the group of terms referring to sexual organs and activities was such that after the grammatical information following each headword, a style marker, nyadzo, a shortened form for chinyadzo (something that is coarse, vulgar or obscene), was introduced, which was then followed by the description of meaning. Where 
they exist, synonyms were given after the definition, and were indicated by FAN, which is a truncated form for -fanana (same as). The style marker nyadzo was meant to be a warning to the reader that the term may be offensive. By giving such a warning, the editors were simply trying to be courteous to their readers. To illustrate this, the treatment of mhata, mboro and beche in DGC can be considered.

mhata K- Z 9>10. (nyadzo) Mhata mwena uri pamuviri wemunhu, unowanikwa pasi panoperera muzongoza, unoshandiswa kuburitsa tsvina mudumbu. FAN horo 9, mukosho 3, mudhidhi 3, mutinhi 3, mupedzazviyo 3.

(The anus is a hole in the body of a human being, found below the hips, through which faeces are removed from the stomach.)

mboro K- Z 9>10. (nyadzo) Mboro inhengo yemuviri wemunhurume kana mhuka inoburitsa weti neurete. FAN chirombo 7, mbonausiku 9, chombo 7, chirema 7 .

(The penis is a part of the body of a male person or animal through which urine and sperm pass.)

beche [mheche] K- z 5>6 map-. (nyadzo) Beche inhengo yemunhukadzi inowanikwa pakati pemakumbo, uye ine buri, panova ndipo panozobuda napo weti kana mwana ava kuzvarwa, asi nechomukati zvichinge zvambobva kwakasiyana. FAN sikarudzi 9, mukana 3, kunzira 17.

(The vagina is a part of a female person found between the legs and having a hole, which passes urine and a child during birth, although internally these come from different locations.)

To strike a balance between being explicit and being euphemistic when it came to defining these words, the editors agreed on a policy explained in the style manual of the dictionary: that the male and female sexual organs, for example, were to be defined in terms of their location on a person's body and their use for non- or less sensational functions such as urinating and child bearing. This is evidenced from the definitions provided for a penis and a vagina, for example. Whilst urinating is one of the main functions of these two organs, it may not be the one people immediately think of when hearing these terms. Generally, people think of sex and related activities, those that are deemed more obscene than urinating. However, although the editors may be blamed for omitting some of the functions of these organs (and mentioning others) the editors may not be accused of misrepresenting these organs. Although the definitions do not mention everything about the penis or vagina, no one can fail to identify the organs once the above descriptions have been read. In the definition of penis, for example, the lexicographer tried to make the definition quite clear and complete whilst also doing so as unsensationally and neutrally as possible. The lexicographer gives a definition that touches only on the essential and ordinary functions of the penis, that is, passing urine and sperm but omitting, for example, the crucial fact that it is also used for having sex. It is true 
that by leaving this last function unmentioned, the lexicographer did not do enough justice to the definition of the term. However, this should be understood against the factors already discussed above. In describing the functions of this organ, more euphemisms were used. For example, the use of the term urete for sperm is a euphemism, the explicit term being uronyo. Lastly, the lexicographer provided more neutral and euphemistic synonyms. When, for example, one refers to a penis as chirombo (a huge creature), mbonausiku (something that sees at night) and chombo (a weapon) or to a vagina as sikarudzi (one that creates a family) or mukana (a passage), no one can visualise the sexual act in the same manner than when the terms mboro and beche are used. By providing some euphemistic near-equivalents, the lexicographers actually made available to the users of the dictionary a number of other possible terms that can be used in place of the ones considered coarse, vulgar or obscene.

Another category of offensive terms which posed challenges with regard to defining was that consisting of quite a substantial number of terms used to refer to groups of people generally regarded as inferior in society. Under this category, can be found those offensive words referring to people of foreign origin, the coloured community, albinos and cripples. To illustrate this, the word mubwidi (a bwidi) can be taken as an example. Some Shona speakers use this term to refer to people of Malawian origin, who came to Zimbabwe during the colonial era to work as migrant labourers on mines and farms. The term is believed to come from the way these people speak. There is a general belief amongst people who use this term that the language of the migrant labourers is not comprehensible or understandable to native Shona speakers. The explanation for the origin of this name is the idea that the speech of these people sounds as if they were only pronouncing a meaningless bwidi bwidi bwidi. Because of this, anyone who speaks in this way has become known as a mubwidi. Whether this is correct or not, the fact remains that this term is being used in some Shona-speaking communities to mock and disparage the way the vabwidi speak and it offends anyone being referred to as such. This is also reinforced by the fact that people of foreign origin are often concentrated in very poor communities, usually on mines and farms, where they provide unskilled labour.

Another example whose nuances are closely related to those of mubwidi is the term mukarushu which refers to people of Mozambican origin. These are people, usually young boys, who fled the Mozambican civil war in the early 1980s to come and work as cattle herders on communal lands in some parts of Zimbabwe. Here karushu, the cashew nut, commonly found in some parts of Mozambique, has been used to identify these cattle herders who feel disliked and unwelcome when referred to by this name. Yet another example is the term murungudunhu, which is used to refer to an albino. This is a compound noun formed by joining murungu (white man) and dunhu (village), that is, a white man of the village. Of the same origin is murungudondo (white man of the forest), which is another name for an albino. The connotations behind both these names are that a person whose colour is white but who has been born of 
black parents are mockingly and disparagingly referred to as a white man who is usually seen as very superior, but is now described as originating from the village or the forest, in this way being accorded an inferior status.

After some of the connotations characterising the use of these words had been looked at, the way the editors of DGC tried to describe the terms bwidi, mukarushu and murungudondo can now be considered.

bwidi D- Z 5>6. (tuko) Bwidi izwi rokutuka rinoshandiswa kureva munhu wechiMalawi.

(Bwidi is a derogatory term used to refer to a person of Malawian origin.)

mukarushu DDKD- Z 1. (manje) Mukarushu izita rinopiwa vanhu vaitiza hondo kuMozambiki vachiuya muZimbabwe.

(Mukarushu is a name for people who fled to Zimbabwe from the war in Mozambique.)

murungudondo D- Z 1. (tuko) Uyu munhu ane ganda jena asi akaberekwa navabereki vatema zvichikonzerwa nourema hwokushaya utema muganda make. FAN musope 1 .

(This is a person whose skin colour is white but whose parents are black. The white skin colour is caused by deficiency of black pigmentation in the skin.)

Just as in the case of terms referring to sexual organs where the style marker, nyadzo, has been used, the style marker, tuko (a shortened form of chituko, insulting word), has been used in the above examples to warn readers that the terms have derogatory connotations. (This is with the exception of the style marker for slang, manje, which has erroneously been given at mukarushu.) However, as can be seen from the definitions provided for these terms vis-à-vis the explanations given for the origins of these terms, the definitions seem to be deficient since they omit much detail. The idea behind the provision of very brief descriptions was to be courteous to the groups of people being referred to. But it could be asked whether this courteousness would help any user understand how these terms are actually used in certain communities. Some would argue that being forthright would show some measure of insensitivity, but, at the same time, it can also be argued that omitting much detail as in the case of the above examples is counter-productive for it leaves out much needed information, especially about the reason(s) why the term(s) should be avoided. For example, describing bwidi only as a person from Malawi may not be a complete enough description since not all people from Malawi are mabwidi, this term only being used specifically to refer to the unskilled labourers who are now permanently residing in Zimbabwe and whose children can no longer be identified as Malawians. Trying to balance these two important aspects is the problem with which the editors of DGC had to struggle, yet it is a challenge with which every responsible lexicographer has to deal. 


\section{Conclusion}

This article has tried to highlight some of the challenges lexicographers face when it comes to the treatment of sensitive vocabulary in their dictionaries. It has attempted to describe some of the difficulties dictionary-makers sometimes experience when they need to strike a balance between the demands of their trade and the expectations of their readers. Drawing concrete examples from Shona, the article has shown that it is sometimes very difficult to follow lexicographic principles of accuracy, explicitness and precision when describing offensive terms such as those referring to sexual and excretory organs and their products, as well as some derogatory words. The article has indicated that good lexicographic practice moves between being theoretically sound and being culturally sensitive. It has shown that being theoretically sound may lead to a socially unacceptable product whilst being culturally sensitive may result in a poor reference tool. Although illustrative examples were drawn only from Shona and from the class of offensive words, the challenges discussed in this article may be applicable to all defining situations, though with possible variations regarding different cultures and lexicographic traditions.

\section{References}

Béjoint, H. 2000. Modern Lexicography: An Introduction. Oxford: Oxford University Press.

Chimhundu, H. (Ed.). 1996. Duramazwi reChiShona. Harare: College Press.

Chimhundu, H. (Ed.). 2001. Duramazwi Guru reChiShona. Harare: College Press.

Dubois J. and C. Dubois. 1971. Introduction à la lexicographie: Le dictionnaire. Paris: Larousse.

Holder, R.W. 1995. Oxford Dictionary of Euphemisms. Oxford: Oxford University Press.

Jackson, H. 1988. Words and Their Meaning. London/New York: Longman.

Kahari, G.P. 1996-97. Review of Duramazwi reChiShona. Southern African Political and Economic Monthly 10(3-4): 33-38, December-January.

Landau, S.L. 1984. Dictionaries: The Art and Craft of Lexicography. New York: Cambridge University Press.

Mberi, N.E. et al. 1997. Response to Professor G. Kahari's Review of Duramazwi reChiShona. The Herald, 20 March, Features Section: B2-B4, B7.

Mberi, N.E. et al. 1997. Was the Dictionary Review Motivated by Hate? Southern African Political and Economic Monthly 10(7): 21-24, April.

Sinclair, J. et al. (Eds.). 1995. Collins COBUILD English Dictionary. London: HarperCollins.

Svénsen, B. 1993. Practical Lexicography: Principles and Methods of Dictionary-Making. Oxford/New York: Oxford University Press.

Trench, R.C. 1857. On Some Deficiencies in Our English Dictionaries. Transactions of the Philological Society: 1-70. London: Parker.

Zgusta, L. 1971. Manual of Lexicography. The Hague: Mouton. 